\title{
WOMEN AND LEADERSHIP IN MODERN AFRICAN LITERATURE: A FOCUS ON CHINUA ACHEBE'S ANTHILLS OF SAVANNAH
}

\author{
Ngozi Ezenwa-Ohaeto* \& Ifeyinwa Success Asuzu* \\ http://dx.doi.org/10.4314/og.v15i1.2s
}

\begin{abstract}
The discourse on women is one which cannot be over- emphasized. The United Nations in its Declaration on the Elimination of Discrimination Against Women in 1980, made expansion of opportunities for women as a key demand. The declaration contends among others, greater the participation of women in decision making. Hence, the present study examines women and leadership in modern African literature to account for their (women) involvement and the impact of their participation cum non participation, focusing on Chinua Achebe's Anthills of Savannah. The aim is to ascertain women leadership and its impact in the wider society, with reference to Chinua Achebe's Anthills of Savannah. The study adopts Feminism (Post structural perspective) as its theoretical consideration. Finding from the study shows that women are not adequately represented in leadership positions. However, in cases where they lead, they functioned optimally for the betterment of their society. Beatrice, for instance, a Senior Assistant Secretary in the Ministry of Finance, is a noble female leader who by her role and conduct stood out. She affected those around her positively and was a source of inspiration to Ikem, a male character, in the novel.
\end{abstract}

Keywords: Leadership, Gender, Participation, Adequately, Women, Inspiration.

\section{Introduction}

It is observed that women generally are underrepresented in leadership. In politics, in the family, in churches and even in literature written by men, women are structurally positioned to act as second fiddle. According to the 2006 Nigerian population census figure, women constituted $49 \%$ of the total population, yet, there has been a gross gender gap between men and women, especially in political representation, economic management and leadership. 
Ogirisi: a new journal of African studies vol. 15s 2019

Morolake notes that: "in Igbo land during the pre-colonial times, the Obi (male monarch of Onitsha ruled in parley with the Omu (female monarch)".It is no longer so in the present day, Igbo. Women have become marginalized. In the $8^{\text {th }}$ National Assembly, out of the 360 members of the House of Representative only 15 are female and out of the 109 Senators only 6 are females. At the State level, women are also marginalized. This situation persists not because women are not willing to lead or because they are weak but because Nigeria has entrenched patriarchal: It is not women's incapability or lack of ambition but limited opportunities created by the Culture, which limits women and places them on second fiddle. Okeke reacting to this says: "systemically gendered cultural, social and structural arrangements that informed women leadership choices relative to their male colleagues" (239). This situation promotes gender inequality which in-turn reduces economic growth as proposed by Canagarajah Klasen and Lawson (2007).

A giant step towards achieving a balanced representation though, was taken in 2006, when the Federal Council of Nigeria approved the National Gender Policy for the nation. This approval was followed by a bolder step in 2008, when the Federal Ministry of Women Affairs and Social Development under its National Gender Policy Strategic Framework (Strategic development Results Framework) launched its implementation plan, an exercise that took eight months to complete. The timeline for the implementation was given - 2009 - 2013. The Implementation Plan mandated among others, the Federal Ministry of Education and the Nigeria Education Research and Development Council (NERDC) to produce school curricular for primary and secondary schools that will reflect the changing gender roles. These policies only ended on paper, as they were hardly implemented and seem forgotten. The present study seeks to examine women in leadership positions in order to account for their involvement and non-involvement in leadership using Achebe's Anthills of Savannah. The study also seeks to find out how well women represent when given leadership positions.

Chinua Achebe is a seasoned writer fondly called the "father of African literature". The gender role of men and women, as well as societies' conceptions of the associated concepts, are frequent themes in his writing. He has been criticized as a sexist author, in response to what many call the uncritical depiction of traditionally 
Ezenwa-Ohaeto \& Asuzu: Women and Leadership in Modern African ...

patriarchal Igbo society, where the most masculine men take numerous wives, and women are beaten regularly. Paradoxically, Igbo society immensely values individual achievement but also sees the ownership over or acquisition of women as a signifier of success. As seen in Things Fall Apart, Igbo society condemns violence but Okonkwo's ability to control 'his' women is inextricably connected to his dignity. Thus, women are automatically disenfranchised in terms of achieving high status related to personal achievement. Others suggest that Achebe is merely representing the limited gendered vision of the characters, and they note that in his later works, he tries to demonstrate the inherent dangers of excluding women from society. It is also suggested that Achebe purposefully created exaggerated gender binaries in order to render Igbo history recognizable to international readers. According to Wikipedia, the representation should not be taken literally; rather, the reader should consider the roles of both women and men as intentionally stark and in opposition. In any case, a careful reading of Achebe paradoxically recognizes the hyperbolic representation of gender politics in Igbo society, while acknowledging the necessary nuance that gives Achebe's women some agency and prominence.

Anthills of Savannah is Achebe $6^{\text {th }}$ novel. Financial times reports that in Anthills of Savannah Achebe has written a book which is wise, exciting and essential, a powerful antidote to the cynical commentators from 'overseas' who see nothing ever new out of Africa. "It is argued that even when women and their lives are more centrally depicted in literature, the male writer continues to be the visionary while the woman is the 'sign' of changes to come" (web). Achebe un-turn this notion in Anthills of the Savannah, where a female is his central character. This is the captivating motive of engaging the novel in the present discourse. The study aims to show the degree of leadership prominence Achebe accorded his female heroine, Beatrice Nwanyibuife, and also show the representation of women in leadership position in Nigeria.

\section{Research Methodology}

This research uses qualitative research method. This is because the major sources of data for the study include the primary texts: Chinua Achebe's Anthills of Savannah Other books, journals, articles from internet, as well as personal opinions. The research deals on 
character analysis.

\section{Theoretical Framework}

This research is predicated on feminist literary theory. Feminist literary theory evolves as a reaction to women's subjugation, abuse, marginalization, and degradation. Feminist theory examines the pervasiveness of gender inequality. According to Susan James, feminism is grounded on the belief that women are oppressed or disadvantaged by comparison with men, and that their oppression is in some way illegitimate or unjustified' (576). The primary concern of feminism is therefore to eliminate mistreatment and unequal treatment of women (Sherry 14). Feminism refers to movements aimed at establishing and defending equal political economic and social rights and equal opportunities for women (http://wikipedia.org/wiki/Feminism).

Feminism has been divided into various perspectives such as liberal, radical, socialist, Marxist, Postmodern, Post structural and eco feminism. This coincides with Rosemary Tong's view that feminist theory is not one but many theories or perspectives and each feminist theory or perspective attempts to describe women's oppression, to explain its causes and consequences and to prescribe strategies for women's liberation' (2). Liberal feminism is a belief that women should receive the same rights and treatment as men. Some critics have argued that one of the shortcomings of liberal feminism is its tendency to accept male values as universal. Radical feminists maintain that sexism is the first most widespread form of human oppression. For this group,

Women's subordination is not rooted in relation of production but in specific relations of reproduction and sexuality that the use of word and language affect our psyche on the definition of men and women. They point to the effectiveness of the capacity of language to shape our thoughts and desires. (Makama 119)

Post structural feminism challenges dominant masculinity views of knowledge by using strategies of opposition, resistance, and deconstruction. Post structural feminists view subjects as socially 
Ezenwa-Ohaeto \& Asuzu: Women and Leadership in Modern African ...

constructed and reject essentialism. According to Post structural feminists, the subjection of women is a sequel to the presupposed disparity between men and women. Drawing from Judith Butler's perspective to sexual difference and gender identity, Butler rejects the essentialist binary model of sexual difference and gender identity. She argues that there is no pre-discursive, primordial identity, all is within discourse, there is no I' outside language since identity is a signifying practice, and culturally intelligible subjects are the effects rather than the causes

of discourses that conceal their workings' (145). Butler proposes that the identity of persons are not socially institutional but emerges as a result of the cultural emergence of those incoherent' or discontinuous' gendered beings who appears to be persons but who fail to conform to the gendered norms of cultural intelligibility' (23). Butler states that if gender identity becomes intelligible, it will disrupt the representation of identities that defile the conventional rule that gender must follow from sex. Even though this appears as a failure within the cultural intelligibility domain, Butler sees it as an avenue to expose and dismantle the domain of intelligibility and also to open up with the very terms of that matrix of intelligibility rival and subversive matrices of gender disorder' (24). Butler considers gender to be variable, volitional and freefloating with the consequence that man and masculine might just as easily signify a female body as a male one, and woman feminine a male body as easily a female' (10).

Butler suggests that gender is sediment through ritualized repetitions of conduct by embodied agents. She views gender as something that is susceptible to deconstruction. Borrowing on Nietzche's rule, she defines gender as a doing', an act that one enacts, an identity constituted through a stylized repletion of acts. For Butler, there is no doer behind the deed, the doer becomes formed from the doing, and there is no gender identity behind the expression of gender; that identity is performatively constituted by the very expressions that are said to be its results' (33). Gender therefore, in Butler's terminology is the repeated stylization of the body, a set of repeated acts within a highly rigid regulatory frame that congeal over time to produce the appearance of substance, of a natural sort of being' (43) Butler cites drag as one of the most noticeable forms of gender performativity in that it creates a parody 
of established gender norms. Drag performances reveal that genders are copies without originals, in imitating gender, drag implicitly reveals the imitative of gender itself as well as its contingency' (137). Gender is therefore, neither true nor false, neither real nor apparent, neither original nor denied (180).

Gender, then, in Butler's view is not constantive but performative, and drag fully subverts the distinction between inner and outer psychic space and effectively mocks both the expressive model of gender and the notion of a true gender identity' (174).

The feminist approach in used, is derived from Butler's Poststructural model. The use of Post structural feminist theory reveals patriarchal genealogies and delegitimizes their centrality to society.

\section{Review of Literature}

The issues of women and inadequate leadership representation have been vastly researched by many scholars and have long lingered, right from the time of colonial administration. Chukukere notes that: "colonial officers failed to perceive the political contributions of women, believing that politics is a man's exclusive domain" (4). According to Ohaeto: 'a basic implication of this is that the few leadership positions required for administration/governance at that time were all filled up by men' (xv). In collaboration to the above, Okafor and Akokuwebe underlines that: "In many African countries, such as Nigeria, obnoxious social norms, political exclusion and economic lopsidedness dictate the presence and voice of women in public life. As men have control over assets..., they have a dominant position in terms of political power. For instance, men councilors may not necessarily be highly educated but such positions are not given to women who have the same low educational level with them' They further explains that: 'Men's participation in leadership will focus more on issues of men's interest than on women's concerns". They observe that: 'In some cases, women are elected into a leadership position in the arm of government without actually participating in actual leadership' They concluded that: 'for there to 
Ezenwa-Ohaeto \& Asuzu: Women and Leadership in Modern African ...

be greater participation of women in all spheres of Nigerian society, government and other stakeholders should engage in programmes and policies that would empower women politically, socially and economically'. (web). Also, the military era provided women with the least opportunity to challenge the structure of gender inequalities, as military promoted female subordinate position in the society, particularly, through the 'First Lady' syndrome (a process which hindered the 'woman's question' from being addressed within the mainstream development praxis (Aina, 2012). Under such arrangements, the women in question were treated within the private interests of wives of political leaders (a mentality which is almost difficult to erase even within the party politics and democratic governance).

Msila, in a similar study submits that stereotypes, societal expectations and the patriarchal society culture are some of the aspects that ensure that women never progress to the helm of organizations meanwhile; women's access to managerial position continues to be an item that is first on the transformation agenda. The study contends that societies can enhance organization's effectiveness when women are in management and leadership positions. It illustrates women experiences in educational management and notes that every society needs to realize the dynamic organization and diversity that women managers bring concluding on the note that addressing women's access to managerial positions is one pertinent aspect in redressing the past as well as existing gender imbalances (89)

Orji Eze remarked that: "women have risen with great urgency in defence of themselves and particularly so in the area of globalization" (in Ohaeto's Ed 33). In spite of these concerted efforts however, Eze notes how sad it is that there are several cultural norms, beliefs and harmful traditional practices in many African societies which deny women their rights to diverse facets of life. He further explains that: "gender inequality in human society is seen in the imbalance of power" (34). In a similar vein, Ngozi Ohaeto reviewed the implication of Igbo-gender based expressions. She highlights such expressions as: 'Ulu kana di' meaning 'it is more beneficial to have a husband', 'Onweghi ihe e'ji ego nwaji eme' meaning 'a woman's money is useless' and some others in same likes and argues that such expressions are one of the numerous 
attempts by men to keep the women in their 'space'; the space of inferiority as created and instituted by men for their interest. She further claims that such expression demeans the woman and impact negatively on the overall being of the female gender. (102). When derogatory expressions are employed continually on a woman, she naturally feels inferior, losses self-esteem and retracts to her shell or 'space'. The overall outcome of this is that women will keep being inadequately represented in leadership.

Lumby and Azaola observe that women bring a different set of values and qualities to leadership when compared to men. They explained this using the role of mothers in family institutions. As the mothers manage their families, they inculcate the idea of sharing among members of the household. As mothers cook and feed families, they magnify the value of sharing among family members. The family and the village are also crucial in sharing motherhood duties, even when the mother is present. All these are crucial values in leadership today; shared leadership; participative leadership and understanding the different individuals within an organization. The motherhood qualities can enhance leadership in organizations. Attributes such as caring and listening are some important qualities that mothers practice and these help with the organization's growth. These roles manifest themselves in varying ways in organizations where women lead. Yet, the society tends to view mothering as an antithesis to leadership roles. They refute the idea that motherhood and womanhood are too soft for leading. Mai Vu, however, observes that some female leaders can be 'too mothering'. According to Mai $\mathrm{Vu}$ this is when the female leader starts to believe that the organization cannot do without her (she takes on too much) because she cannot stand the thought that her followers might fail so she tries to be overprotective, forgetting her own needs, wants and boundaries. Mai, however opines that despite these disadvantages, mothering can be a boon to any organization. Mothering quality gives women the ability to juggle a number of roles within leadership. (Lumby and Azaola 47)

As earlier noted, women are making vigorous efforts to redress the 'Women Palavar'. For Ezeigbo literature is an instrument to restore justice, equity and dignity to African woman. She submits that women were the first custodians of oral literature being the first set of story tellers in traditional society and thus should have taken 
Ezenwa-Ohaeto \& Asuzu: Women and Leadership in Modern African ...

the centre stage in literary creative writing. She queries why women were absent from the first crop of storytellers whose literary production formed the initial corpus of African literature? Ezeigbo answered her question, stating that women's denial to western education was the most crucial hindrance to their early arrival to the literary scene (3). However, when they eventually came 'late', it was with so much creative energy and passion to fight for gender equity. "They demonstrated that women have the ability to succeed as political leaders, professionals and captains of industry and commerce (Ohaeto and Nwajiaku Ed 9).

From the foregoing, it can be agreed without doubt, that women are trying hard to get out of the mold of patriarchy. Female writers via their scholarly contributions shout out, to ensure that the African woman is not trampled under feet. The present study therefore, is an attempt to promote women leadership and enhance the existing literature on gender discourse.

\section{Synopsis of the Novel}

Anthills of Savannah is a satire of political oppression and ruthless dictatorship in a typical African state. The setting is a fictional postindependence West African State of Kangan, which has a striking resemblance to contemporary Nigeria. It is a drama of love, friendship and death involving three close friends and former school mates, Sam, Chris, and Ikem who later finds themselves in different but interrelated positions in the country's political terrain. Sam is now His Excellency, the military Head of State; Chris is now his Commissioner for Information while Ikem is now the Editor of the government-owned newspaper, the National Gazette, ealier edited by Chris before his latest appointment. However, as the press and the government are normally strange bed fellows, Sam soon finds himself on a collision course, first with Ikem, who uses the newspaper to pioneer and fight a relentless crusade against his corrupt and oppressive regime, and later with Chris who rejects a presidential order to put Ikem under check by suspending him. The embattled Editor, who coincidentally comes from the volatile Abazon Province, is subsequently falsefully implicated in a fictitious plot by some Abazonians to overthrow the government. Consequently, he is wrongfully removed as Editor, arrested later and killed by security agents while Chris goes into hiding and he is 
declared wanted. In the course of his escape trip, news comes that the brutal regime has been overthrown, while the president has been kidnapped by unknown persons, tortured and buried in a shallow grave (p. 219). Chris is shot dead in an attempt to rescue a young girl from being raped by a drunken police sergent, thus becoming the last of the three friends to meet with violent death. Meanwhile, Beatrice and Elewa, the women in the lives of Nkem and Chris respectively, do their best to preserve their memory and offer some hope for the still uncertain future.

\section{Woman Leadership in Anthills of Savannah}

Beatrice Nwanyibuife Okoh, is the heroine of the novel, Anthills of Savanna. Beatrice is popularly called 'B' or 'BB'. Nwanyibuife or 'Buife' for short means "A female is also something", arising from the fact that she is the fifth female child in a row born when her mother was desperate for a male child. Hence, Beatrice resents the name, especially the 'nwanyi' the female half of it (75).

She is the Senior Assistant Secretary in the Ministry of Finance and, as His Excellency introduces her, 'the only person in the service, male or female, with first-class honours in English, not from a local university but from Queen Mary College, University of London. His Excellency further, attests to the sound academic prowess of Beatrice, saying “. . . our Beatrice beat the English to their game (75). She plays a crucial role to prevent Chris, her lover from being arrested during the massive manhunt for him. In this regard, she receives help from the most unexpected source - a sympathetic member of the security forces, Captain Abdul Medani, who continues secretly (as a ghost telephone caller) to provide her with hints of their next move after the search conducted on her house led by him. She is bold and brave. When she was lured into a private dinner by His Excellency to enable her hear Chris and Ikem being condemned by a foreign journalist, she boldly confronts the Head of State for such calculated mischief (15). After the murder of Ikem, Beatrice takes Elewa under her wing, offering her protection, guidance and solace, especially as Elewa is already in the family way. The news of Chris sudden death shattered Beatrice. She only manages to distance herself from her thoughts after several weeks by her even greater concern for 'Elewa's threatened miscarriage' (p.218). Her final role is to organize a naming ceremony for Elewa's 
Ezenwa-Ohaeto \& Asuzu: Women and Leadership in Modern African ...

baby girl, and proceed to perform the 'rituals' in the absence of Elewa's mother and uncle who arrive only after the baby has been named 'Amaechina', which means 'May-the-path-never-close' (Incident 9.2.37). This tones down the gloom and pessimism of the novel.

As an independent woman in the city, Beatrice strives for the balance that Okonkwo lacked so severely in Arrow of God. Lumby and Azaola once assert that: "that women bring a different set of values and qualities to leadership when compared to men" She refutes the notion that she needs a man, and slowly learns about Idemili, a goddess Total emancipation, freedom and liberation from patriarchy refuted patriarchy and embraced learning. Here, Achebe, depicts the woman as strong, knowledge driven individuals who engage the supernatural in their affair. It is generally observed that humans, especially women depend on the supernatural for inspiration and strength.

Beatrice is portrayed as the most dominant female character in the novel. Unlike Achebe's novels, Beatrice role and relevance becomes increasingly pronounced as the action progresses. Indeed, from the moment of Ikem's murder and Chris's going into hiding, Beatrice takes centre-stage and dictates the pace of action which is sustained even after the death of Chris. Beatrice though, a heroine, was not at the fore of event when Chris and Ikem were at the scene. She did not function until Chris and Ikem were no more in the scene. Achebe silenced his hero. This shows subjugation. By her role and conduct, Beatrice becomes a champion of feminism and women's liberation. This is brought about by her solitary nature and independence of mind which are attributes cultivated from childhood. Furthermore, Beatrice demonstrates a prophetic insight into future events and is now and again referred to as a 'priestess' (pp.114 \& 116) with a 'goddessy' personality (p.199). The author at the end made his heroine play demeaning role but Beatrice remains firm in her conviction that women should not be limited to such capacities.

From the novel, it can be argued that Achebe did not see his heroine best for role especially at the initial stage. He couldn't let the woman take the full lead. He would portray her in many ways that would make her not seem superior. Beatrice role expanded after the demise of Ikem and Chris. 


\section{Women Leaders in Nigeria}

Nigeria is the most populous black nation in the world and has, from historical times, produced women leaders and achievers who blazed the trail in their various professions and continue to excel in their endeavors in areas such as medicine, pharmacy, public administration and other professions., women who spear- headed the 1929 Aba Women's Riots in South-Eastern Nigeria. Professor (Mrs.) Grace Alele-Williams who not only distinguished herself in the field of mathematics, but also rose to become the Vice-Chancellor of the University of Benin-the first female Nigerian academic to be so honoured (Nduka, 2001). Similarly, late Prof. Dora Nkem Akunyili (OFR), who was the former Director of National Agency for Food and Drug Administration and Control reduced the incidence of fake drugs from about $90 \%$ to $68 \%$ of drugs in 2001(Akunyili, 2006). Again, Dr. (Mrs.) Ngozi Okonjo-Iweala, successfully transformed the Nigerian economic platform when she succeeded in negotiating a debt relief package for Nigeria as the Finance Minister (July, 2003June, 2006) under the Obasanjo regime and also Spear- headed the unpopular fuel subsidy removal policy by the Nigerian government, which led to protests in January 2012 under the Goodluck Jonathan regime (Aina, 2012; McGroarty, 2012). Also, she stressed the need to reduce the country's recurrent expenditure, which is currently $74 \%$ of the national budget, and embark on capital projects which could improve the $14 \%$ unemployment rate in the country (Osa-Okunbor, 2012). Dr. Stella Mogekwu, the immediate past Rector, of the Delta State Polytechnic, Ogwashi- uku and a cousin to Dr. (Mrs.) Ngozi Okonjo-Iweala, is a woman worthy of note. She knew her powers as a leader and used it optimally, to effect development in the school, especially in the area of structures and infrastructural development. Though, her tenure was not without its challenges.

Women leaders abound, not just in politics, but also in academia, Mrs. Kuti, for instance a school teacher and, Founder and President of the Nigerian Women's Union, was prominent long before Beijing and similar conferences. Again, in literature there are outstanding women writers who have championed and brought international acclaim to the nation. Despite women leadership prowess, women are not adequately represented in leadership positions in many African countries; this is reflective in literature written by men. Okafor and Akokuwebe have however observed that 
Ezenwa-Ohaeto \& Asuzu: Women and Leadership in Modern African ...

some progress was made in the past Nigerian government of President Goodluck Jonathan, to give more women opportunities to serve as leaders in various capacities than any other previous administration. (web). This is true, however it was still not adequate. Moreover, the number has descended with the present Buhari administration.

\section{Recommendations}

There are so many things that could be done to enhance women's participation in leadership in Nigeria. However, the research identifies the following:

- Unity: Women should be united in purpose and support their fellow women who either in power or aspiring for a leadership position. There is an Igbo adage; 'Igwebuike' meaning 'unity is strength'. Women should infuse the 'igwebike' spirit in pursuit for leadership positions and balanced representation. Any leadership position a woman occupies, she should occupy boldly, firmly and resultfully', bearing in mind that leadership is from God. As in the case of Achebe's heroine, Beatrice, who refutes the notion that she needs a man, and slowly learns about Idemili, a goddess balancing the aggression of male power.

- Courage and persistence: Women should be courageous and persistence in their struggle for adequate representation. This can be gotten through words, actions, personal decision and change of weak ideologies. Women should be determination on the part of women to assume leadership positions in the public and private sectors. There should be democratic and equitable participation in development process through office holding to give control over the allocation of resources.

- Modeling and support: Women who have broken the mold should model other women and provide meaningful support in form of advice, encouragement, money etc. This will go a long way to encourage some less privileged woman, who can become stronger via the opportunity.

- Education and Learning: Acquisition of formal and informal education should be ensured. Acquisition of right 
Ogirisi: a new journal of African studies vol. 15s 2019

leadership skill is also important. Women should make relentless efforts to nurture their inherent leadership deposit through continual learning. Discourses on women right to leadership and gender equality should be sustained. Furthermore, the traditional structure 'Umuada forum' and other such structures should be dismantled. Women should desist from punishing their fellow women because of a men's misdeed. Women should be united first for their interest as women. Again, the government on its part should ensure mass adult literacy and schooling for girls.

\section{Conclusion}

Women are not adequately represented in leadership, this is evident from the study; the extent and manner in which Achebe portrays his female heroine. However, in cases where women lead, they function optimally to the betterment of the society. It therefore behooves on women to take the lead in ensuring that they are adequately represented via aspiring for and where it has to be contested, contest for leadership positions, as expecting men to easily release leadership positions that will reflect a balanced representation of both sexes will be 'waiting for 'Godot' that might never come.

Finally, any woman in leadership position, in whatsoever capacity, should promote 'matriachy' through excellence, integrity and hard- work, just like Dora Akunyili of blessed memory, NgoziOkonjo Iweala, and Beatrice, Achebe's heroine, to take the lead.

\section{*Ngozi Ezewa-Ohaeto, Ph.D \& *Ifeyinwa Success Asuzu \\ Department of English Language and Literature \\ Nnamdi Azikiwe University, Awka, Nigeria \\ ifeyinwais82@gmail.com}




\section{References}

Achebe, Chinua. Anthills of Savannah. Anchor. 1987.

Lumby, J., \& Azaola, M.C. Women principals in South Africa: Gender, mothering and leadership. British Educational Research Journal,40(1): 30-44.2014

Okafor, Emeka Emmanuel and Akokuwebe, Monica Ewomazino. Women and Leadership in Nigeria: Challenges and Prospects in Developing Country Studies www.iiste.orgISSN 2224-607X (Paper) ISSN 2225-0565 (Online) Vol.5, No.4, 20151

Ugwuja, Amaechi. Women and Wealth Creation in Nigeria's Presumed Recession Aftermath: Feminist Political Economy Perspective in Ngozi- Ezenwa Ohaeto and Ijeoma Nwajiaku (Ed).Prof Ezenwa Resource Centre. 2019.

Mai Vu Coach. Female leaders: Are you too mothering Female Executive? Retrieved from maivucoach.com/leadership/female -executive/ Accessed 13 October 2019.

Morolake, Omonubi- McDonnel. Gender Ineguality in Nigeria. Spectrum Book Limited. 2013

Ngozi Ezenwa- Ohaeto Recreating Femality: Reviewing the implication of Igbo gender-based expression in PREORC Journal of Arts and Humanities. Vol. 1.1 : 92-114, 2016

Msila Vuyisile Women and leadership: Learning from an African Philosophy Msila, V \& Gumbo, M.T(Eds.), Africanizing the Curriculum: Indigenous Perspectives and Theories. Stellenbosch: Sun Press 2016, pp83-97.

Wikipedia the Free Encyclopaedia. Feminism. Retrieved 22, October, 2019 from http://en.wikipedia.orgwiki/Feminism. $\underline{2019}$ 